\title{
Anthocyanin Compounds of the Persian Sour Cherry (Prunus cerasus L) as the Fruit with High Antioxidant Properties
}

\author{
Fatemeh Mollaamin $1,{ }^{*} \mathbb{D}$, Fatma Kandemirli ${ }^{2}$ (D) , Majid Monajjemi ${ }^{1}$ (D) \\ Department of Chemical engineering, Central Tehran Branch, Islamic Azad University, Tehran, Iran \\ 2 Department of Biomedical Engineering, Faculty of Engineering and Architecture, Kastamonu University, Kastamonu, \\ Turkey \\ * Correspondence: smollaamin@gmail.com (F.M.);
}

Scopus Author ID 35848813100

Received: 10.05.2021; Revised: 15.06.2021; Accepted: 18.06.2021; Published: 13.08.2021

\begin{abstract}
In this work, it has been explained that the significant parameter for increasing the absorbed amount in a direct non-linear track to moving from the Beer-Lambert principle is the self-conjoint of anthocyanins of cy, dp, and pt compounds. The shifting of enthalpy between acn$\mathrm{Al} 3+/ \mathrm{Ga} 3+/ \mathrm{Cr} 3+/ \mathrm{Fe} 3+/ \mathrm{Mg} 2+$ liaison compounds has been studied the double conjunctions and carbonyl groups due to the linkage of B ring for cy, dp, and pt of anthocyanins in vacuum and water ambiance debating the strongness and color of acn- $\mathrm{Al} 3+/ \mathrm{Ga} 3+/ \mathrm{Cr} 3+/ \mathrm{Fe} 3+/ \mathrm{Mg} 2+$ linkage of cy, $\mathrm{dp}$, and pt structures in a weakly acidic medium in the Iranian sour cherry. The ACNs including Cy, Dp, and $\mathrm{Pt}$ within the largest linkage in the strong part of these compounds by metal cations of $\mathrm{Al}^{3+} / \mathrm{Ga}^{3+} / \mathrm{Cr}^{3+} / \mathrm{Fe}^{3+} / \mathrm{Mg}^{2+}$ cause a different limit of colors under acidic $\mathrm{pH}$. Besides, the charge density and electron charges have been received by matching the electrostatic capacity to a constant charge of $\mathrm{O}^{+}{ }_{17}, \mathrm{O}^{+}{ }_{16}$, and $\mathrm{O}^{+}{ }_{7}$ particles for $\mathrm{cy}-\mathrm{M}^{\mathrm{n}+}(\mathrm{n}: 31), \mathrm{dp}-\mathrm{M}^{\mathrm{n}+}(\mathrm{n}: 32)$ and $\mathrm{pt}-\mathrm{M}^{\mathrm{n}+}(\mathrm{n}: 35)$, using the electrophilic parts of cy, dp and pt anthocyanin unities thet indicate the mouvement and the resistance of these structures in the reel samples like persian sour cherry.
\end{abstract}

Keywords: Persian sour cherry; anthocyanin; anthocyanin-metal linkage; Beer-Lambert principle; $\mathrm{Cy}$; Dp; Pt; vacuum; water.

(c) 2021 by the authors. This article is an open-access article distributed under the terms and conditions of the Creative Commons Attribution (CC BY) license (https://creativecommons.org/licenses/by/4.0/).

\section{Introduction}

These days, one of the large groups of pigments is anthocyanins, which are the secondary metabolite part of flavonoids, amenable for the fruits and vegetables color, and the other saving sources in plants. So, the aromatic ring structures of anthocyanins are a portion of principal structures as flavonoids synthesized via the phenylpropanoid pathway discovered in roots, stems, leaves, flowers, and fruits through_Iranian sour cherry.

Some of the most popular anthocyanidins in some fruits and vegetables with cyanidin, delphinidin, pelargonidin, peonidin, malvidin, and petunidin is about $50,12,12,12,7$, and 7 percent [1].

In the natural world, the ring of cyanidin in berries is a reddish/purple principal pigment and red/colored vegetables such as red in the sweet potato and the purple corn [2, 3]. Delphinidin has a chemical characteristic similar to most anthocyanidins. [4-7].

The studies on nutrition and trees by antioxidant factors have commenced to the multiple information with their impacts. [8-11].Fruits and vegetables have the chemical https://biointerfaceresearch.com/ 
structures linked to health promotions through Iranian sour cherry to react with different ideas in many natural structures [12-21].

The particle substitutions affect the physicochemical properties of anthocyanin structures due to changing the size, polarity, and solubility in the water toward an expanded range of compounds in nature [22-24].

So, the preliminary results of the induction of anthocyanin biosynthesis in sour cherry (P. cerasus L) have been indicated. Oxygen radical absorbance capacity (ORAC) assay and Trolox equivalent antioxidant capacity assay on fruit and callus extracts have also been performed to evaluate the extracts' antioxidant activity [25-27].

Around $\mathrm{pH}=3$, changing the color generates the colored anthocyanin cation, $\mathrm{AH}^{+}$, which alters into colorless or near-colorless samples (Scheme 1) [28].<smiles>OC1=Cc2c(O)cc(O)cc2O[C@H]1c1ccc(O)c(O)c1</smiles>

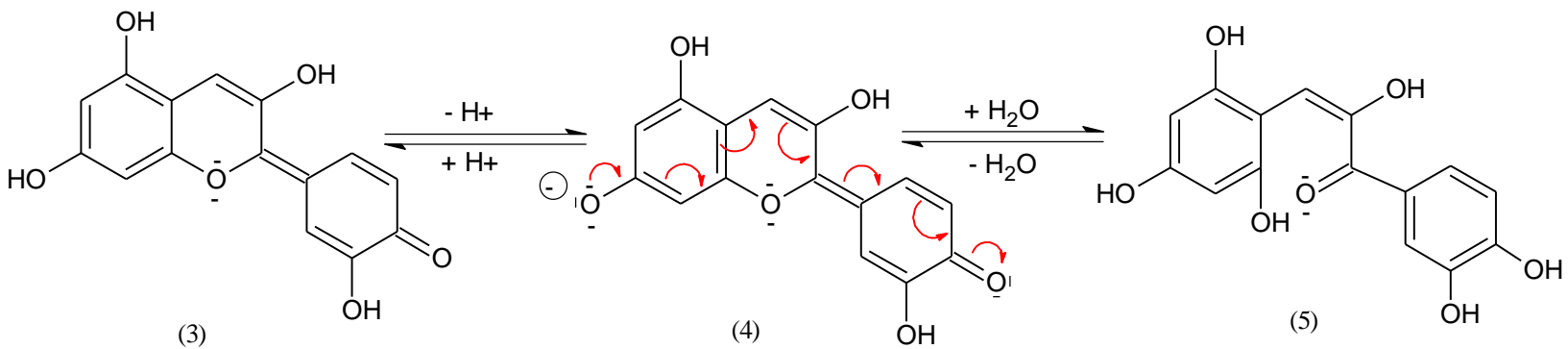

Scheme 1. The anthocyanidin pigments reveal a variety of molecular transformations with the $\mathrm{pH}$ changes, and generating different colors; (1) (flavylium cation) $\mathrm{pH}>3$ red, (2) carbinol pseudo base ( $\mathrm{pH}=4-5$ colorless), (3) anhydrobase ( $\mathrm{pH}=6-7$ violet),(4) anhydrobase anion ( $\mathrm{pH}=7-8$ blue), (5)chalcone ( $\mathrm{pH}>8$ yellow).

The structures of anthocyanin water-soluble and polar derivatives with a wide membrane-bound vesicle in the cell's cytoplasm can be observed in various colors in a large limit of colors like black, purple-blue, and red (Scheme 2a) [29-31].

Glińska and his co-workers have illustrated the decrease of potential toxic effects of ACNs through separating chela manganese $(n+)$ tion of these compounds [32]. To form metallic cation linkage and express purple-blue colors in competing with the hydrogen ions for the binding sites (Scheme 2b) [33].

The linkage of $\mathrm{Al}^{3+} / \mathrm{Ga}^{3+} / \mathrm{Cr}^{3+} / \mathrm{Fe}^{3+} / \mathrm{Mg}^{2+}$ by $\mathrm{Cy}, \mathrm{Dp}$, and $\mathrm{Pt}$ has been more largely studied through the relation with the blue coloration of hydrangea floral structures. So, strong compounds between $\mathrm{Dp}$ and $\mathrm{Al}^{3+}$ have been investigated to form acidified ethanol and a wide $\mathrm{pH}$ range [33-37].

Therefore, a theoretical study of the linkage between the electronic and chemical structure of $\mathrm{Al}^{3+} / \mathrm{Ga}^{3+} / \mathrm{Cr}^{3+} / \mathrm{Fe}^{3+} / \mathrm{Mg}^{2+}$ by $\mathrm{Cy}$, Dp, and $\mathrm{Pt}$ and their stability has been followed. Moreover, the structural properties of $[\mathrm{ACN}-\mathrm{Al} 3+/ \mathrm{Ga} 3+/ \mathrm{Cr} 3+\mathrm{Fe} 3+/ \mathrm{Mg} 2+]$ linkage conserving their stability and color tide for Iranian sour cherry. 
(a)

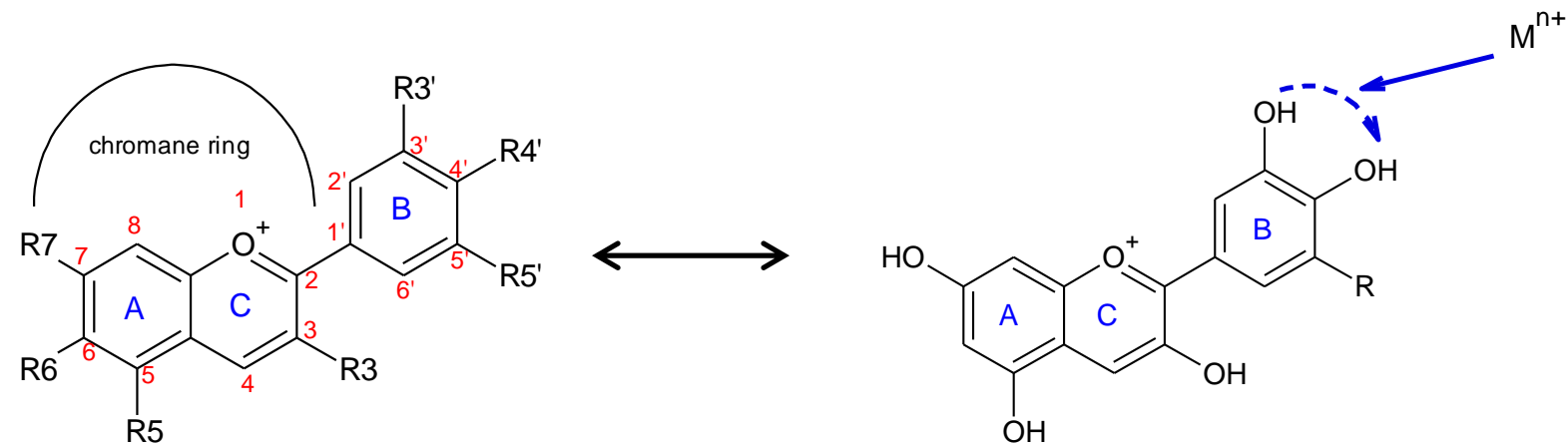

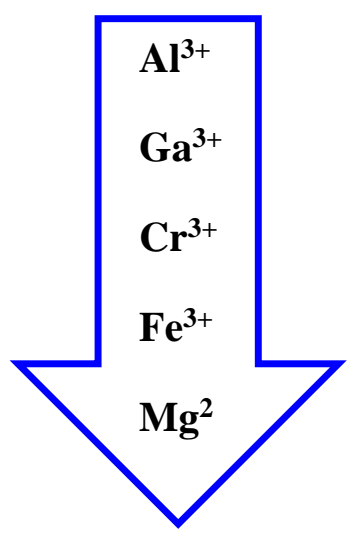

(b)
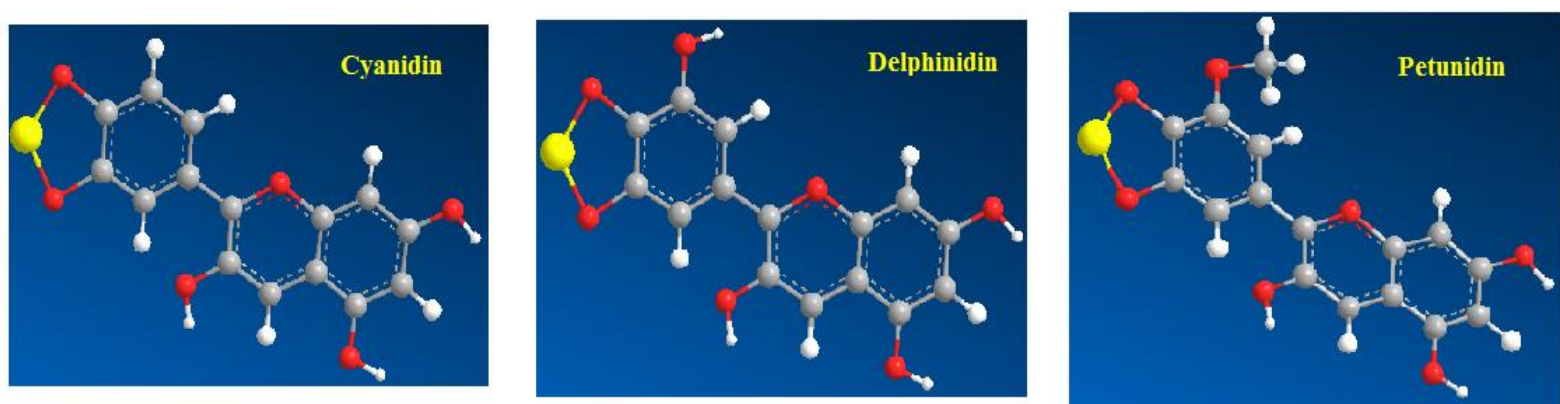

Scheme 2. a) Basic anthocyanin structure. b) Proposed mechanism of ACN- metal cation linkage of $\mathrm{Al}^{3+} / \mathrm{Ga}^{3+} / \mathrm{Cr}^{3+} / \mathrm{Fe}^{3+} / \mathrm{Mg}^{2+}$ through the $\mathrm{B}$ ring for three anthocyanins of Cyanidin, Delphinidin and Petunidin.

\section{Materials and Methods}

The linkage of anthocyanins of Cyanidin, Delphinidin, and Petunidin with $\mathrm{Al}^{3+} / \mathrm{Ga}^{3+} / \mathrm{Cr}^{3+} / \mathrm{Fe}^{3+} / \mathrm{Mg}^{2+}$ has been studied for finding the minimized coordination of [ACN$\left.\mathrm{Al}^{3+} / \mathrm{Ga}^{3+} / \mathrm{Cr}^{3+} / \mathrm{Fe}^{3+} / \mathrm{Mg}^{2+}\right]$ linkage with infrared computations and following the Bee Lambert Rule using the Gaussian09 program package [38-44].

So, the minimized geometry of [Cyanidin- $\mathrm{Al}^{3+} / \mathrm{Ga}^{3+} / \mathrm{Cr}^{3+} / \mathrm{Fe}^{3+} / \mathrm{Mg}^{2+}$ ] linkage (Scheme 2) through the $\mathrm{B}$ cycle in vacuum and water ambiance at $300 \mathrm{~K}$ have been measured in the table 1 and Figure 1a,b.

Table 1. Minimized coordination of $\left[\mathrm{ACN}-\mathrm{Al}^{3+} / \mathrm{Ga}^{3+} / \mathrm{Cr}^{3+} / \mathrm{Fe}^{3+} / \mathrm{Mg}^{2+}\right]$ linkage extracted of Scheme 2.

\begin{tabular}{|c|c|c|c|c|}
\hline $\begin{array}{l}\text { Cyanidin-metal } \\
\text { ion chelate }\end{array}$ & bond length & (̊̊) & bond angle & $\left({ }^{\circ}\right)$ \\
\hline \multirow{2}{*}{$\mathrm{Cy}-\mathrm{Mg}^{2+}$} & $\mathrm{O}(10)-\mathrm{Mg}^{2+}(31)$ & 1.99 & \multirow{2}{*}{$\mathrm{O}(10) \cdots \mathrm{Mg}^{2+}(31) \cdots \mathrm{O}(27)$} & \multirow{2}{*}{112.83} \\
\hline & $\mathrm{Mg}^{2+}(31)=\mathrm{O}(27)$ & 1.99 & & \\
\hline \multirow[t]{2}{*}{$\mathbf{C y}-\mathbf{A l}^{3+} / \mathbf{C r}^{3+}$} & $\mathrm{O}(10)=\mathrm{Al}^{3+} / \mathrm{Cr}^{3+}(31)$ & 1.82 & \multirow{2}{*}{$\begin{array}{c}\mathrm{O}(10)-\mathrm{Al}^{3+} / \mathrm{Cr}^{3+}(31) \\
\mathrm{O}(27)\end{array}$} & \multirow[t]{2}{*}{121.20} \\
\hline & $\mathrm{Al}^{3+} / \mathrm{Cr}^{3+}(31) \cdots \mathrm{O}(27)$ & 1.82 & & \\
\hline
\end{tabular}




\begin{tabular}{|c|c|c|c|c|}
\hline $\begin{array}{c}\text { Cyanidin-metal } \\
\text { ion chelate }\end{array}$ & bond length & $(\AA)$ & bond angle & $\left({ }^{\circ}\right)$ \\
\hline \multirow[t]{2}{*}{$\mathrm{Cy}-\mathrm{Fe}^{3+}$} & $\mathrm{O}(9) \stackrel{\cdots \cdots}{-} \mathrm{Fe}^{3+}(32)$ & 1.81 & \multirow[t]{2}{*}{$\mathrm{O}(10) \cdots-\mathrm{Fe}^{3+}(31) \cdots \cdots(27)$} & \multirow[t]{2}{*}{121.66} \\
\hline & $\mathrm{Fe}^{3+}(32) \cdots \mathrm{O}(26)$ & 1.81 & & \\
\hline \multirow[t]{2}{*}{$\mathrm{Cy}-\mathrm{Ga}^{3+}$} & $\mathrm{O}(10) \cdots \mathrm{Ga}^{3+}(31)$ & 1.89 & \multirow[t]{2}{*}{ 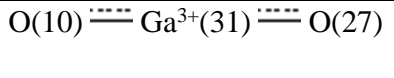 } & \multirow[t]{2}{*}{117.55} \\
\hline & $\mathrm{Ga}^{3+}(31)=\mathrm{O}(27)$ & 1.90 & & \\
\hline
\end{tabular}
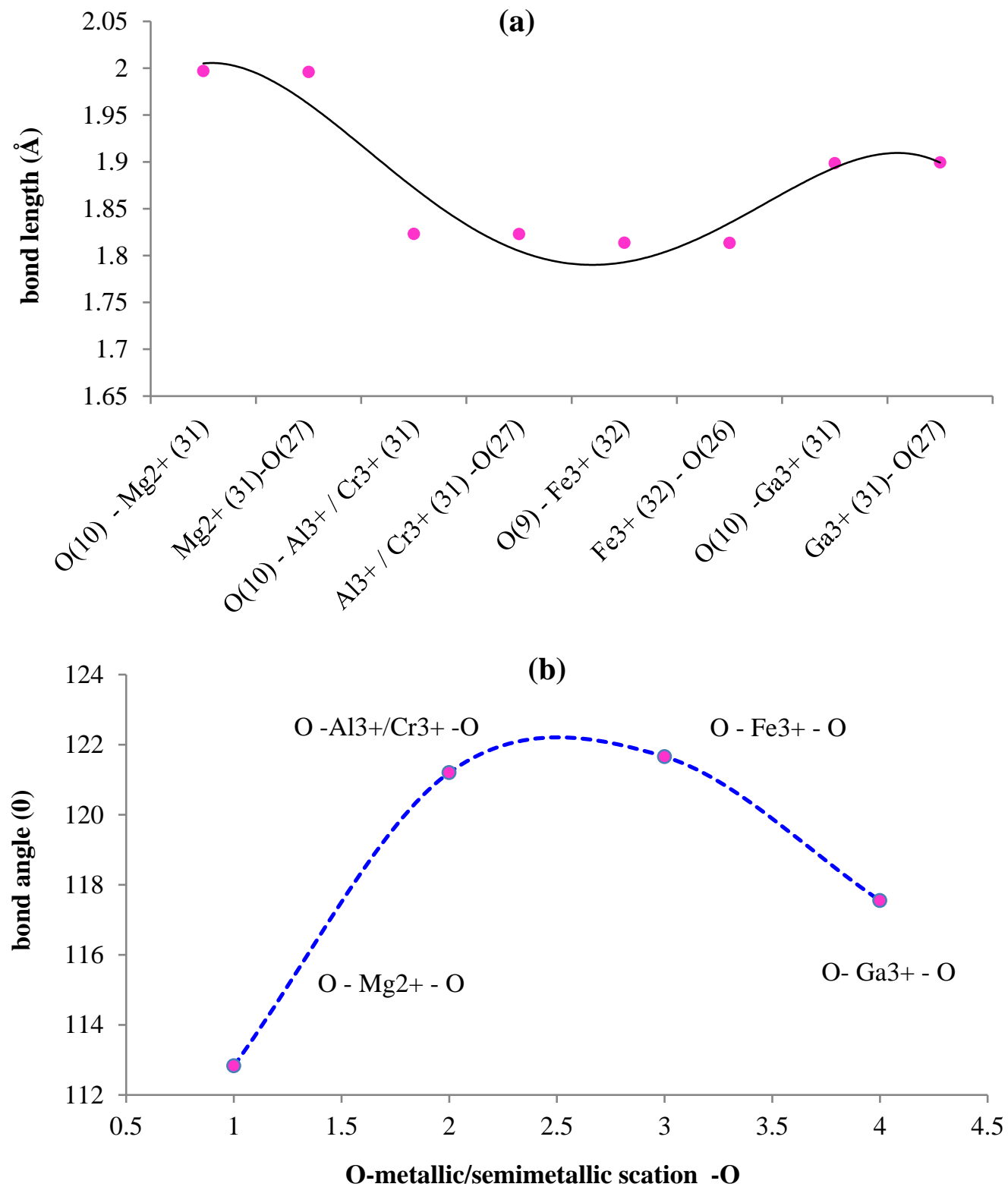

Figure 1. Minimized geometry of (a) bond length; (b) bond angle for $\left[\mathrm{ACN}-\mathrm{Al}^{3+} / \mathrm{Ga}^{3+} / \mathrm{Cr}^{3+} / \mathrm{Fe}^{3+} / \mathrm{Mg}^{2+}\right.$ ] linkage extracted of Table 1.

The PCM is the most common SCRF model on apparent slab charges granding to debate non-electrostatic effects with certain theories based on Pierotti's or modified subsequently by Claverie $[45,46]$.

The most popular methods of the SCRF level of multiple expanding have been studied with an algorithm of a serious multipolar growth by Frisch that exists at both semi-empirical and ab initio units of theory. So, has been arranged a tension for different continuum solvation temples of multiple growths (MPE) of the solute charge diffusion, and thus, Onsager-SCRF was developed by researchers for the Gaussian program [47-51].

In fact, the dielectric continuum samples like the self-consistent reaction field method are sufficient in using the long-range solute-solvent electrostatic interactions and the impact of 
solvent polarization. The other unit is a mixture of molecular mechanics (MM) solvent molecule with quantum mechanics level $(\mathrm{QM})$ for the electronic structure of the solute molecule (QM/MM) inadequacy of the dielectric continuum model [52,53]. In this study, Cyanidin, Delphinidin, and Petunidin have been led to a description of Monte Carlo (MC) simulation by potential energy in 300K energy via time scale (0-100) (Table 2). Optimal values are close to 0.5 . Varying the step size can have a large effect on the acceptance ratio. The MC Options dialog box permits us to set up the MC simulation parameters toward the good agreement data by calculating the relation confidence for these compounds; $\mathrm{R}^{2}$ cyanidin $=0.8237$, $\mathrm{R}^{2}$ delphinicin $=0.8964, \mathrm{R}^{2}$ petunidin $=0.9208,($ Figure 2$)$.

Table 2. Calculated potential energy (kcal/mol) via the Monte Carlo method for Cyanidin, Delphinidin and Petunidin.

\begin{tabular}{c|c|c|c|c|c|c|c} 
Time & Cyanidin & Delphinidin & Petunidin & time & Cyanidin & Delphinidin & Petunidin \\
\hline $\mathbf{0}$ & 66.29 & 85.55 & 98.12 & $\mathbf{2 5}$ & 38.33 & 44.21 & 61.21 \\
\hline $\mathbf{1}$ & 66.10 & 77.00 & 99.71 & $\mathbf{2 6}$ & 35.65 & 43.90 & 63.55 \\
\hline $\mathbf{2}$ & 62.63 & 72.86 & 88.19 & $\mathbf{2 7}$ & 35.53 & 46.64 & 66.68 \\
\hline $\mathbf{3}$ & 57.71 & 67.86 & 87.14 & $\mathbf{2 8}$ & 36.61 & 46.98 & 65.47 \\
\hline $\mathbf{4}$ & 55.51 & 66.56 & 85.37 & $\mathbf{2 9}$ & 37.56 & 48.40 & 66.82 \\
\hline $\mathbf{5}$ & 58.64 & 63.43 & 82.58 & $\mathbf{3 0}$ & 38.60 & 48.15 & 61.60 \\
\hline $\mathbf{6}$ & 54.39 & 61.05 & 81.29 & $\mathbf{3 1}$ & 38.65 & 49.22 & 60.39 \\
\hline $\mathbf{7}$ & 53.42 & 58.78 & 75.34 & $\mathbf{3 2}$ & 41.63 & 44.47 & 58.94 \\
\hline $\mathbf{8}$ & 52.48 & 56.56 & 72.91 & $\mathbf{3 3}$ & 39.58 & 46.41 & 60.26 \\
\hline $\mathbf{9}$ & 53.58 & 55.48 & 69.31 & $\mathbf{3 4}$ & 37.75 & 45.38 & 56.94 \\
\hline $\mathbf{1 0}$ & 50.14 & 52.64 & 71.75 & $\mathbf{3 5}$ & 37.21 & 45.79 & 56.31 \\
\hline $\mathbf{1 1}$ & 45.88 & 51.56 & 70.64 & $\mathbf{3 6}$ & 36.87 & 48.75 & 54.53 \\
\hline $\mathbf{1 2}$ & 47.26 & 52.01 & 76.98 & $\mathbf{3 7}$ & 38.29 & 51.62 & 60.65 \\
\hline $\mathbf{1 3}$ & 46.01 & 49.44 & 75.16 & $\mathbf{3 8}$ & 39.75 & 54.51 & 64.85 \\
\hline $\mathbf{1 4}$ & 43.10 & 47.21 & 71.12 & $\mathbf{3 9}$ & 42.13 & 50.76 & 61.00 \\
\hline $\mathbf{1 5}$ & 38.42 & 47.05 & 68.66 & $\mathbf{4 0}$ & 43.52 & 49.37 & 58.32 \\
\hline $\mathbf{1 6}$ & 37.30 & 47.68 & 68.68 & $\mathbf{4 1}$ & 40.32 & 47.74 & 58.94 \\
\hline $\mathbf{1 7}$ & 37.59 & 49.40 & 68.99 & $\mathbf{4 2}$ & 45.76 & 46.02 & 59.45 \\
\hline $\mathbf{1 8}$ & 39.81 & 46.83 & 69.39 & $\mathbf{4 3}$ & 44.36 & 47.10 & 56.43 \\
\hline $\mathbf{1 9}$ & 42.52 & 46.99 & 66.96 & $\mathbf{4 4}$ & 47.57 & 49.21 & 59.05 \\
\hline $\mathbf{2 0}$ & 42.61 & 49.26 & 69.47 & $\mathbf{4 5}$ & 43.83 & 49.86 & 57.61 \\
\hline $\mathbf{2 1}$ & 39.47 & 54.68 & 74.96 & $\mathbf{4 6}$ & 40.64 & 50.65 & 57.95 \\
\hline $\mathbf{2 2}$ & 36.84 & 52.14 & 70.21 & $\mathbf{4 7}$ & 38.93 & 52.21 & 55.92 \\
\hline $\mathbf{2 3}$ & 38.46 & 46.36 & 67.82 & $\mathbf{4 8}$ & 40.01 & 50.57 & 55.77 \\
\hline $\mathbf{2 4}$ & 37.73 & 42.68 & 62.62 & $\mathbf{4 9}$ & 41.188 & 50.49 & 52.44 \\
\hline $\mathbf{2 5}$ & 38.33 & 44.22 & 61.21 & $\mathbf{5 0}$ & 39.22 & 47.62 & 53.79 \\
\hline & & & & & & &
\end{tabular}

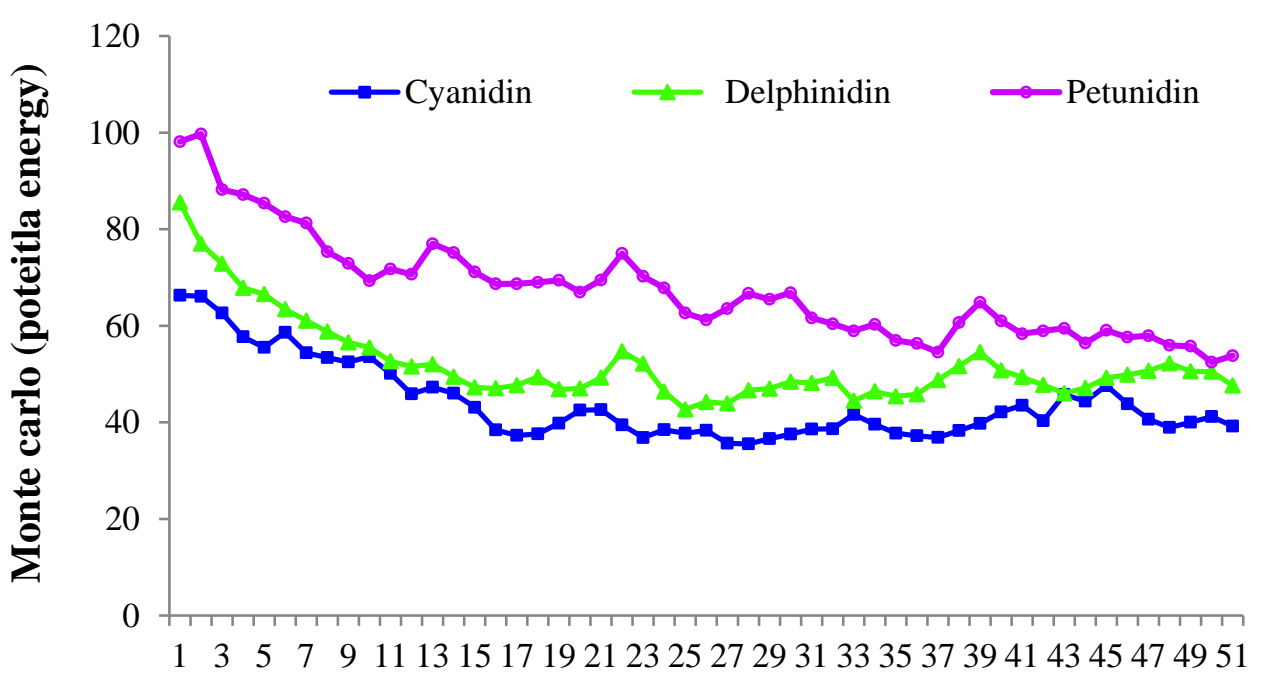

Time

Figure 2. Calculated graphs of potential energy (kcal/mol) via time by Monte Carlo method for Cyanidin, Delphinidin, and Petunidin. 
Basically, for calculating the desired thermodynamic averages [54,55], it is necessary to have some methods available for computation of the potential energy by MC simulation, in the form of a function representing the potential interaction in the molecular mechanics or in the form of direct quantum-mechanical calculations.

Also, it should be noted that constraining potentials have been used at finite temperature, $27^{\circ} \mathrm{C}$ introducing a constraining potential which enables one to define the groups of anthocyanins. Since the constraining potential is artificial, the dependence of calculated thermodynamic properties [54,55] on the form and the radius of the constraining potential must be investigated on a case-by-case basis (Figure 2).

Besides, the Monte Carlo level of theory (MC) applied in simulating physicochemical systems is the classes of the computational algorithm based on repeated occasional_templates for computation of their consequences. Computing pseudo-random or random numbers produces computation accuracy, especially for compound systems, by predicting a reliable and correct response with a deterministic algorithm [40,41].

The new configuration is assigned if the energy comes down and with a probability of $\mathrm{e}^{-\Delta \mathrm{E} / \mathrm{kT}}$ if the energy goes up. The configurations in the ensemble based on the metropolis method respect a Boltzmann distribution, and the probability of accepting higher energy configurations lets Monte Carlo levels go up and escape from a local minimum [42]. Monte Carlo simulations require only the susceptibility to measure the system's energy, which might be advantageous if calculating the first derivative is impossible or time-consuming.

Besides, since only a single point is transferred in each step, only the energy change associated with this motion should be computed, not the total energy for the whole system.

However, Monte Carlo methods are weak, including the absence of the exact time scale and atomic velocities; therefore, these methods are not appropriate for illustrating timedependent reactions or characteristics related to momentum [42].

\section{Results and Discussion}

NMR calculations on the database of three anthocyanin pigments of Cyanidin (Cy), Delphinidin (Dp), and Petunidin(Pt) have been estimated using theoretical methods to measure the effect of metal linkage of Iranian sour cherry, including factorial excess of $\mathrm{Al}^{3+} / \mathrm{Ga}^{3+} / \mathrm{Cr}^{3+} / \mathrm{Fe}^{3+} / \mathrm{Mg}^{2+}$ in different $\mathrm{pH}$ and have been estimated to unravel the indicated atoms in the active sites of these anthocyanin pigments (Figure 3 ).

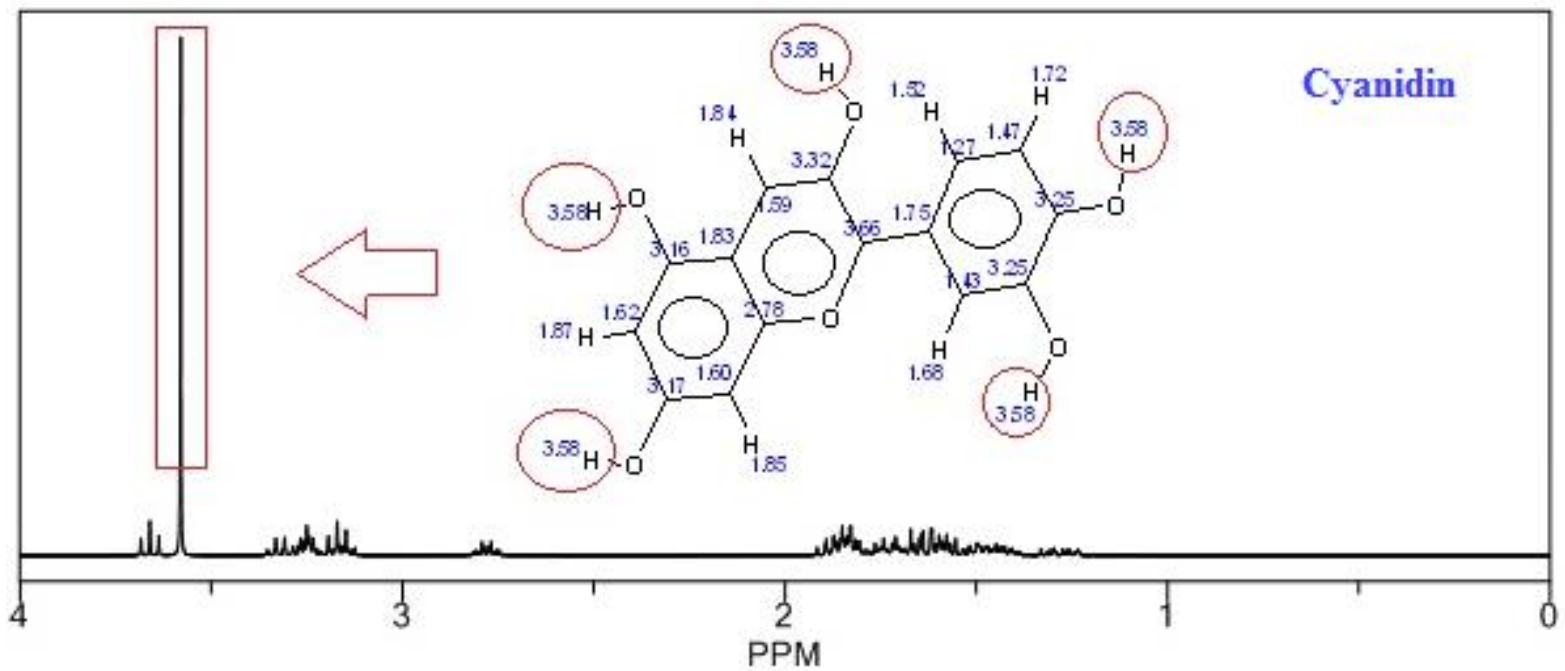



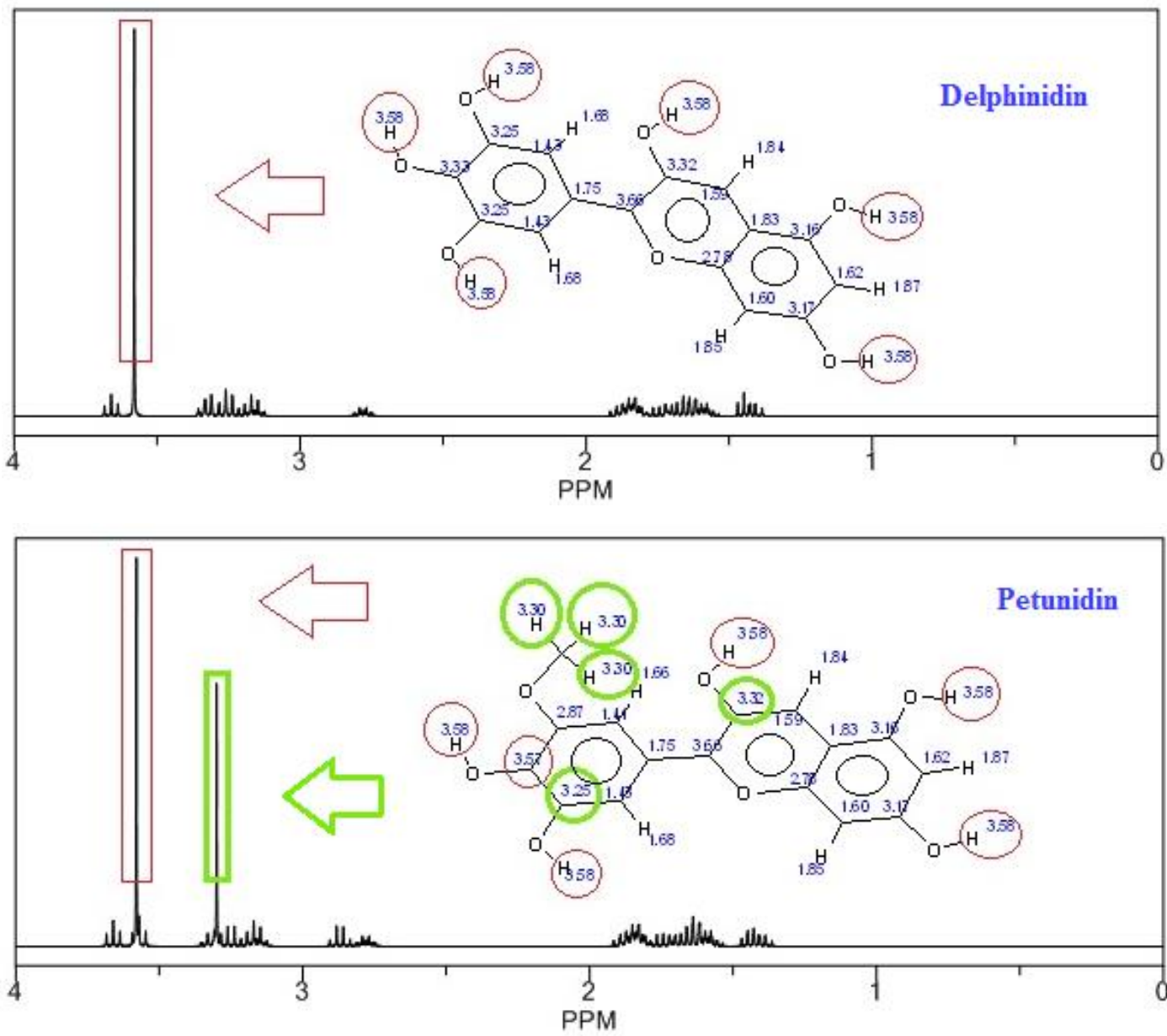

Figure 3. NMR calculations on the database of three anthocyanin pigments of Cyanidin (Cy), Delphinidin (Dp), and Petunidin $(\mathrm{Pt})$.

Moreover, Figure 4 indicates the anthocyanin profiles found in AM cherry extract and in callus extract. The spectra of the separated anthocyanins in sour cherry samples were very similar to those of cyanidin 3-glucoside, the standard used for their quantification (Figure 4).

Cyanidin 3-glucosylrutinoside, cyanidin 3-sophoroside, cyanidin 3-rutinoside, and cyanidin 3-glucoside were identified as major components in the analyzed samples in agreement with the findings previously reported in the literature [25].

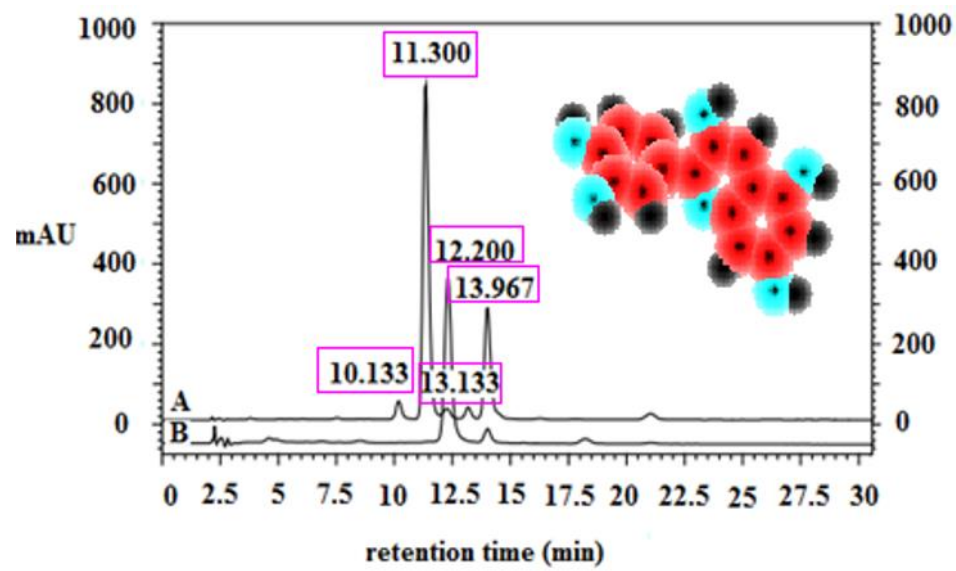

Figure 4. HPLC profile of sour cherry (P cerasus L) cv Amarena Mattarello fruit extract (A) and callus extract

(B). Chromatographic conditions as reported in the test. Identification peaks: cyanidin 3-sophoroside ( $\mathrm{tr}$ 10.133); cyanidin 3- glucosylrutinoside (tr 11.300), cyanidin 3-glucoside (tr 12.200), cyanidin 3-rutinoside (tr 13.967). 
In fact, the absorbance (A) of the anthocyanins- $\mathrm{Al}^{3+} / \mathrm{Ga}^{3+} / \mathrm{Cr}^{3+} / \mathrm{Fe}^{3+} / \mathrm{Mg}^{2+}$, ion linkage of $\mathrm{Cy}, \mathrm{Dp}$, and $\mathrm{Pt}$ pigments in the $\mathrm{H}_{2} \mathrm{O}$ hyper box of a modeled template has been computed with the beer-lambert principle depending on concentration $(\mathrm{c} / \mathrm{mol} / \mathrm{L})$ of $\mathrm{H}^{+}$. The data has been indicated based on $\mathrm{A}=\log _{10}\left(\mathrm{I}_{\mathrm{o}} / \mathrm{I}\right)=\varepsilon \mathrm{lc} ; \mathrm{A}$ is the absorbance; I, the intensity of current; $\varepsilon$, molar absorptivity coefficient; and $\mathrm{c}$, the amount of $\mathrm{Cy}-\mathrm{Al}^{3+}$ and $\mathrm{Pt}-\mathrm{Al}^{3+}$ in stronger $\mathrm{pH}$ (Figure 5a, b) [54,55].

So, these decreases in absorbance might be jointed to the low solubility of the ACNmanganese $(\mathrm{n}+)$ compounds which are concluded in view of some compounds. It has been shown the unbiased $\mathrm{pH}$ and hyperchromic impacts were explored to be highest with much lower manganese $(\mathrm{n}+)$ values; they were largest in higher $\mathrm{pH}$ with manganese $(\mathrm{n}+)$ and $[\mathrm{ACN}]$ and were pursued by absorbance decreases (Figure 5a, b). The large increases in absorbance could also be treated to be changed as the without color samples of ACN for those that absorb and reflect visible light and the manganese $(n+)$ induced linked to ACN compounds (Figure $5 a, b)$.
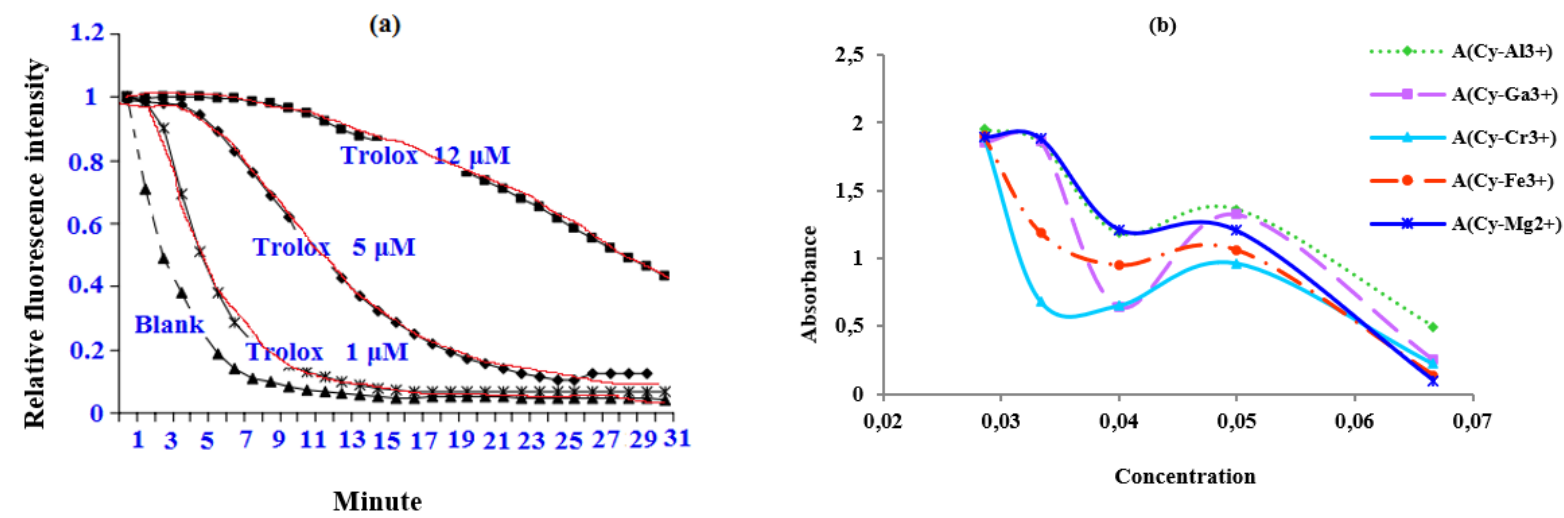

Figure 5. (a) Trolox concentration effect on FL fluorescence decay curve. Data are pooled from two runs. (b) Changes of absorbance (A) versus concentration; (c) through Beer-Lambert law for [Cy- $\mathrm{Al}^{3+} / \mathrm{Ga}^{3+} / \mathrm{Cr}^{3+}$ $\left./ \mathrm{Fe}^{3+} / \mathrm{Mg}^{2+}\right]$ linkage in the weak acidic ambiance by different concentrations of $\mathrm{H}^{+}$at $300 \mathrm{~K}$.

Actually, the RAC values were measured with relationship factor between the Trolox concentration and the pure surface of the FL decay curve and were expressed as Trolox equivalents (TE) as micromole $(\mu \mathrm{mol})$ per $100 \mathrm{~g}$ of fresh weight (FW) (Figure 5a). In this work, it has been found that the important factor for increasing the absorbance in a positive non-linear fashion through deviating from the Beer-Lambert law is the Self-association of ACN (Figure $5 b)$.

There is a high tendency to adsorb cy, dp, and pt by manganese $(+2)$, but the shifts were of the small amount by managing ACN into supramolecular conjunction like manganese $(+2)$ in metalloanthocyanins compounds [37].

Magnesium (2+) is the only divalent metal cation used in this work which is a crucial $\mathrm{M}^{\mathrm{n}+}$ to life system and was found to do function in the stereochemical configurations of $\mathrm{Cy}$, Dp and Pt anthocyanins (Table 1) [56].

To discover the impacts of Al3+ salt on food origin, ACN was evaluated with the objectif to better know the blue color progress of metallo-ACN.

In calculations, $\mathrm{Al}^{3+}$ was identified to displace magnesium (2+) in $\mathrm{ACN}$ - magnesium (2+) compounds, Cy based, and produces more stable compounds [57]. This manganese ( $\mathrm{n}+)$ has also been estimated as a key to evaluating Cy, Dp, and Pt in ACN from food [58]. Similar to magnesium (2+), $\mathrm{Al}^{3+}$ also lacks electrons in $d$ orbitals but is trivalent when ionized. 
In all $\mathrm{pH}$, the frequency, intensity, and absorbance of $\mathrm{ACN}$-linkage were found to be significantly different with each metal treatment $\left(\mathrm{Al}^{3+} / \mathrm{Ga}^{3+} / \mathrm{Cr}^{3+} / \mathrm{Fe}^{3+} / \mathrm{Mg}^{2+}\right)$ [54]. It has been seen that by increasing the $\mathrm{pH}$, the frequency of $\left[\mathrm{ACN}-\mathrm{Al}^{3+} / \mathrm{Ga}^{3+} / \mathrm{Cr}^{3+} / \mathrm{Fe}^{3+} / \mathrm{Mg}^{2+}\right]$ linkage increases as $\mathrm{pH} \approx 1.1-1.5$. The best frequency of aluminum (3+) treated acylated Cy was larger, indicating the development of bluer colors in higher $\mathrm{pH}$ with influences on their considerable range of dispersion (Figure 6) [54].

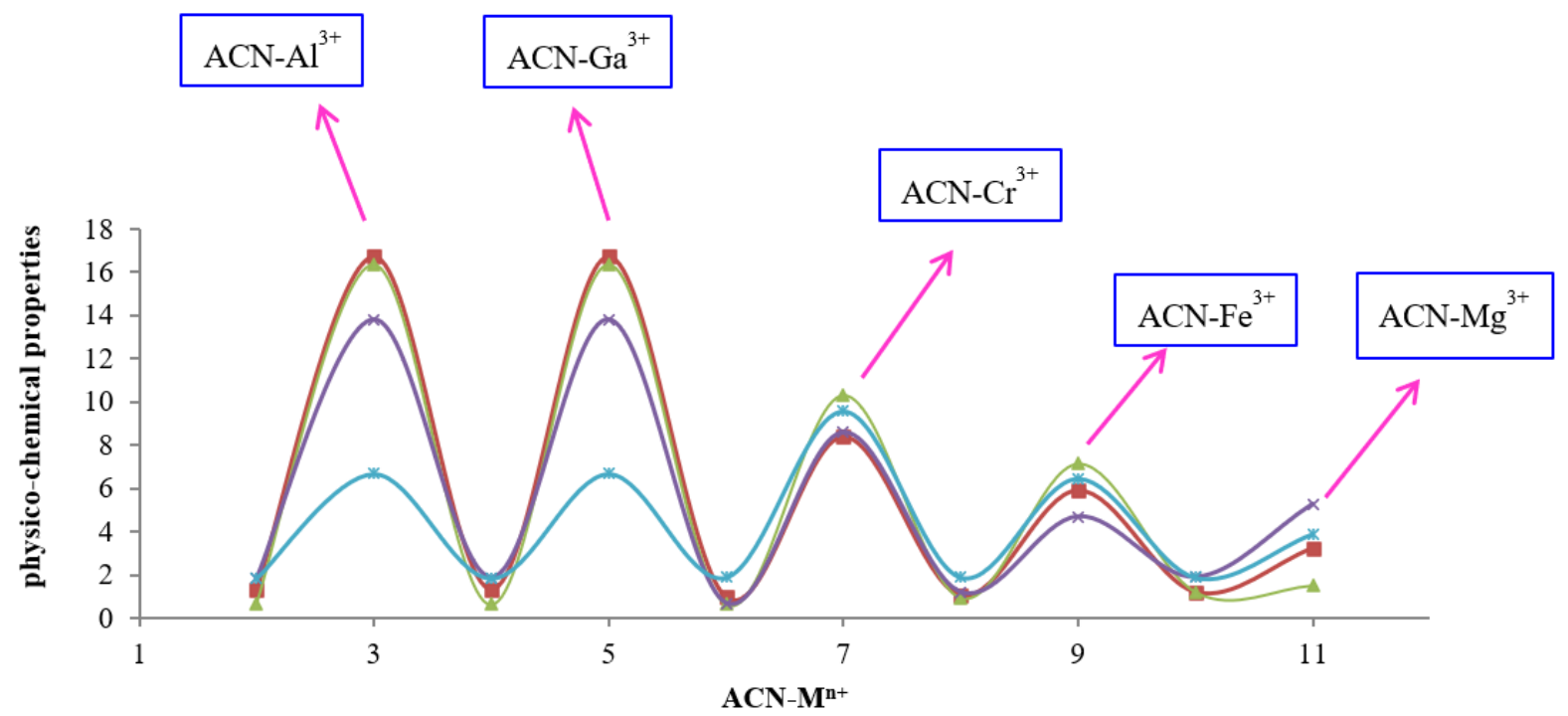

Figure 6. The graph of calculated physico/chemical properties for ACN - manganese $(n+)$ through

Ref.

There is data about the interaction of anthocyanin with chromium (3+). However, it is trivalent manganese $(\mathrm{n}+)$ having electrons in d orbitals, where the anthocyanin of both sources was achieved to be various from one another with each metal cation [54].

Similar trends occurred with $\mathrm{Cr}^{3+}$, where the $\mathrm{F}_{\max }$ of chelated $\mathrm{Cy}$ and $\mathrm{Dp}$ were greater while it has been indicated the larger Fmax of the $\mathrm{ACN}$ with chromium (3+) compared to $\mathrm{Al}^{3+}$ in linkage by $\mathrm{Cy}$ and $\mathrm{Pt}$.

Like $\mathrm{Al}^{3+}$, the impacts of iron chelated to $\mathrm{ACN}$ were investigated to be better it characterized to generate some ACN. Those metalloanthocyanins with Cy chromophores need $\mathrm{Fe}^{3+}$ to generate blue hues[37]., but those based on Dp chromophores can proceed with blue colors. So, it has been seen ACN formed bonds with $\mathrm{Fe}^{3+}$ producing the highest shifted of frequency and absorbance compared to other metalloanthocyanins [54].

As it has been seen in [54], the physical properties of high frequency and dipole moment for anthocyanin-metal cation linkage of $\mathrm{Cy}-\mathrm{Al}^{3+}, \mathrm{Dp}-\mathrm{Al}^{3+}$, and $\mathrm{Pt}-\mathrm{Al}^{3+}$ have been calculated in weakly acidic ambiance extracted from the infrared computational method, which shows a high deviation of absorbance for $\left[\mathrm{Al}^{3+}\right.$ - linkage] of Dp pigment.

The principal frequency vibrational modes have been illustrated based on the stability and color of various anthocyanin-metal cation linkage. It is assumed that including additional diffuse and polarization functions into the basis set used in the calculation always improves the obtained results in theory $[54,59,60]$.

In the next step, the atomic charge of indicated atoms in $\left[\mathrm{ACN}-\mathrm{Al}^{3+} / \mathrm{Ga}^{3+} / \mathrm{Cr}^{3+} / \mathrm{Fe}^{3+}\right.$ $\left./ \mathrm{Mg}^{2+}\right]$ linkage has been evaluated as the active parts of the molecules which play an important role in the electron charge transfer toward producing a range of various colors in a water medium (Scheme 2 and Table 3a-c). 
Table 3a. Atomic charge for oxygen atoms in molecules of [Cyanidin- $\mathrm{Al}^{3+} / \mathrm{Ga}^{3+} / \mathrm{Cr}^{3+} / \mathrm{Fe}^{3+} / \mathrm{Mg}^{2+}-$ linkage] in different ambiance of vacuum (v) and water (w).

\begin{tabular}{|c|c|c|c|c|c|c|c|c|c|c|}
\hline atom & $\begin{array}{c}\mathrm{Cy}-\mathrm{Al}^{3+} \\
(\mathrm{v})\end{array}$ & $\begin{array}{c}\mathrm{Cy}-\mathrm{Al}^{3+} \\
(\mathbf{w})\end{array}$ & $\begin{array}{c}\mathbf{C y}-\mathbf{G a}^{3+} \\
(\mathbf{v})\end{array}$ & $\begin{array}{c}\mathbf{C y}-\mathbf{G a}^{3+} \\
(\mathbf{w})\end{array}$ & $\begin{array}{c}\mathrm{Cy}-\mathrm{Cr}^{3+} \\
(\mathbf{v})\end{array}$ & $\begin{array}{c}\mathbf{C y}-\mathbf{C r}^{3+} \\
(\mathbf{w})\end{array}$ & $\begin{array}{c}\mathrm{Cy}-\mathrm{Fe}^{3+} \\
(\mathrm{v})\end{array}$ & $\begin{array}{c}\mathrm{Cy}-\mathrm{Fe}^{3+} \\
(\mathrm{w})\end{array}$ & $\begin{array}{c}\mathrm{Cy}-\mathrm{Mg}^{2+} \\
(\mathrm{v})\end{array}$ & $\begin{array}{c}\mathrm{Cy}-\mathrm{Mg}^{2+} \\
(\mathrm{w})\end{array}$ \\
\hline 010 & -0.32 & -0.36 & -0.36 & -0.37 & -0.03 & -0.02 & -0.11 & -0.16 & -0.40 & -0.42 \\
\hline $\mathrm{O}^{+} 17$ & -0.13 & -0.12 & -0.11 & -0.16 & -0.12 & -0.13 & -0.12 & -0.13 & -0.17 & -0.13 \\
\hline O24 & -0.19 & -0.18 & -0.18 & -0.23 & -0.18 & -0.21 & -0.21 & -0.21 & -0.22 & -0.20 \\
\hline O25 & -0.21 & -0.20 & -0.20 & -0.22 & -0.20 & -0.21 & -0.21 & -0.21 & -0.22 & -0.21 \\
\hline O26 & -0.22 & -0.20 & -0.21 & -0.20 & -0.21 & -0.21 & -0.22 & -0.21 & -0.23 & -0.21 \\
\hline O27 & -0.33 & -0.33 & -0.35 & -0.33 & -0.09 & 0.07 & -0.14 & -0.13 & -0.39 & -0.39 \\
\hline $\mathbf{M}^{\mathrm{n}+31}$ & -0.01 & -0.02 & -0.03 & 0.75 & -0.86 & -0.44 & 0.02 & 0.07 & 0.77 & 0.76 \\
\hline
\end{tabular}

Table 3b. Atomic charge for oxygen atoms in molecules of [Delphinidin- $\mathrm{Al}^{3+} / \mathrm{Ga}^{3+} / \mathrm{Cr}^{3+} / \mathrm{Fe}^{3+} / \mathrm{Mg}^{2+}-$ linkage] in different ambiance of vacuum (v) and water (w).

\begin{tabular}{|c|c|c|c|c|c|c|c|c|c|c|}
\hline atom & $\begin{array}{c}\text { Dp-Al } \\
(\mathbf{v})\end{array}$ & $\begin{array}{c}\mathbf{D p}-\mathbf{A l}^{3+} \\
(\mathbf{w})\end{array}$ & $\begin{array}{c}\text { Dp-Ga }{ }^{3+} \\
(\mathbf{v})\end{array}$ & $\begin{array}{c}\text { Dp-Ga }{ }^{3+} \\
(\mathbf{w})\end{array}$ & $\begin{array}{c}\mathrm{Dp}-\mathrm{Cr}^{3+} \\
(\mathbf{v})\end{array}$ & $\begin{array}{c}\mathrm{Dp}-\mathrm{Cr}^{3+} \\
(\mathbf{w})\end{array}$ & $\begin{array}{c}\text { Dp-Fe } \\
(\mathbf{v})\end{array}$ & $\begin{array}{c}\text { Dp-Fe } \text { e }^{3+} \\
(w)\end{array}$ & $\begin{array}{c}\mathrm{Dp}-\mathrm{Mg}^{2+} \\
(\mathrm{v})\end{array}$ & $\begin{array}{c}\text { Dp- } \mathrm{Mg}^{2+} \\
(\mathrm{w})\end{array}$ \\
\hline O9 & -0.28 & -0.32 & -0.33 & -0.56 & 0.06 & 0.01 & 0.09 & -0.14 & -0.37 & -0.39 \\
\hline $\mathrm{O}^{+} 16$ & -0.13 & -0.12 & -0.11 & -0.13 & -0.13 & -0.13 & -0.13 & -0.13 & -0.17 & -0.13 \\
\hline $\mathbf{O 2 3}$ & -0.20 & -0.18 & -0.18 & -0.18 & -0.21 & -0.21 & -0.24 & -0.20 & -0.22 & -0.19 \\
\hline $\mathbf{O 2 4}$ & -0.21 & -0.19 & -0.20 & -0.20 & -0.21 & -0.20 & -0.23 & -0.20 & -0.22 & -0.20 \\
\hline O25 & -0.22 & -0.21 & -0.21 & -0.21 & -0.22 & -0.21 & -0.22 & -0.21 & -0.23 & -0.21 \\
\hline 026 & -0.33 & -0.33 & -0.35 & -0.63 & 0.04 & 0.06 & 0.04 & -0.12 & -0.40 & -0.39 \\
\hline O30 & -0.16 & -0.19 & -0.18 & -0.18 & -0.20 & -0.21 & -0.24 & -0.21 & -0.21 & -0.21 \\
\hline$M^{n+32}$ & 0.01 & 0.03 & -0.05 & 0.64 & -0.49 & -0.42 & 0.24 & 0.04 & 0.76 & 0.76 \\
\hline
\end{tabular}

Table 3c. Atomic charge for oxygen atoms in molecules of [ Petunidin - $\mathrm{Al}^{3+} / \mathrm{Ga}^{3+} / \mathrm{Cr}^{3+} / \mathrm{Fe}^{3+} / \mathrm{Mg}^{2+}-$ linkage] in different ambiance of vacuum (v) and water (w).

\begin{tabular}{|c|c|c|c|c|c|c|c|c|c|c|}
\hline atom & $\begin{array}{c}\text { Pt-Al } \\
(\mathbf{v})\end{array}$ & $\begin{array}{c}\text { Pt-Al } \\
(\mathbf{w})\end{array}$ & $\begin{array}{c}\text { Pt-Ga }{ }^{3+} \\
(\mathbf{v})\end{array}$ & $\begin{array}{c}\text { Pt-Ga }{ }^{3+} \\
(\mathbf{w})\end{array}$ & $\begin{array}{c}\text { Pt-Cr }{ }^{3+} \\
(\mathbf{v})\end{array}$ & $\begin{array}{c}\mathbf{P t}-\mathrm{Cr}^{3+} \\
(\mathbf{w})\end{array}$ & $\begin{array}{c}\text { Pt-Fe } \mathbf{F e}^{3+} \\
(\mathrm{v})\end{array}$ & $\begin{array}{c}\mathbf{P t}_{-} \mathbf{F e}^{3+} \\
(\mathbf{w})\end{array}$ & $\begin{array}{c}\text { Pt-Mg }{ }^{2+} \\
(\mathbf{v})\end{array}$ & $\begin{array}{c}\text { Pt- } \mathrm{Mg}^{2+} \\
(\mathrm{w})\end{array}$ \\
\hline $\mathrm{O}^{+7}$ & -0.13 & -0.12 & -0.12 & -0.13 & -0.13 & -0.13 & -0.13 & -0.13 & -0.17 & -0.13 \\
\hline 017 & -0.29 & -0.33 & -0.56 & -0.57 & 0.04 & 0.03 & -0.11 & -0.12 & -0.38 & -0.39 \\
\hline O19 & -0.20 & -0.18 & -0.18 & -0.18 & -0.21 & -0.21 & -0.12 & -0.21 & -0.22 & -0.20 \\
\hline $\mathbf{O 2 0}$ & -0.22 & -0.21 & -0.22 & -0.19 & -0.22 & -0.21 & -0.22 & -0.20 & -0.23 & -0.21 \\
\hline O21 & -0.21 & -0.21 & -0.21 & -0.21 & -0.21 & -0.21 & -0.22 & -0.21 & -0.22 & -0.22 \\
\hline
\end{tabular}

In Tables 3a-c, it has been indicated the shifts of electronic charge of identified oxygen atoms $\left(\mathrm{O}^{+}{ }_{17}, \mathrm{O}^{+}{ }_{16}\right.$, and $\left.\mathrm{O}^{+}{ }_{7}\right)$ and metal cations with minimized [ACN$\mathrm{Al}^{3+} / \mathrm{Ga}^{3+} / \mathrm{Cr}^{3+} / \mathrm{Fe}^{3+} / \mathrm{Mg}^{2+}$ ] linkage (Scheme 2); so, the results of table 3a-c in a polar medium of water solution comparison to vacuum declare the stability and color of these compounds in the natural products of vegetables and fruits.

\section{Conclusions}

Divalent magnesium (2+) was found to impact ACN minimally with raising electron density in different $\mathrm{pH} ; \mathrm{Fe}^{3+} \approx \mathrm{Ga}^{3+}>\mathrm{Al}^{3+}>\mathrm{Cr}^{3+}>>\mathrm{Mg}^{2+}$.

The color of the ACN chelates was discovered to be stable through the analysis and subsequent investigation considering stability that will be followed to estimate the efficiency of these types as food colorants.

Using Beer-Lambert law on $\left[\mathrm{ACN}-\mathrm{Al}^{3+} / \mathrm{Ga}^{3+} / \mathrm{Cr}^{3+} / \mathrm{Fe}^{3+} / \mathrm{Mg}^{2+}\right]$ linkage of $\mathrm{Cy}$, Dp, and Pt pigments by theoretical methods illustrates absorbance factor in vacuum and water ambiance and then unravels the stabilization energy and geometry which have been impacted by NMR theoretical modeling toward the electronic structure of minimized [ACN$\left.\mathrm{Al}^{3+} / \mathrm{Ga}^{3+} / \mathrm{Cr}^{3+} / \mathrm{Fe}^{3+} / \mathrm{Mg}^{2+}\right]$ compounds resulting of metal linkage.

The information has shown that such extrapolation models certainly overestimate the anthocyanin pigments by sharp parts of electrophilic molecules in weakly acidic ambiance with different concentrations of $\mathrm{H}^{+}$, which are the best active structures at the applied compounds in this project for scientists through building up the health-promoting by sour cherry in Iran. 


\section{Funding}

This research received no external funding.

\section{Acknowledgments}

This research has no acknowledgment.

\section{Conflicts of Interest}

The authors declare no conflict of interest.

\section{References}

1. Mattioli, R.; Francioso, A.; Mosca, L.; Silva, P. Anthocyanins: A Comprehensive Review of Their Chemical Properties and Health Effects on Cardiovascular and Neurodegenerative Diseases. Molecules 2020, 25, https://doi.org/10.3390/molecules25173809.

2. Bontsidis, C.; Mallouchos, A.; Terpou, A.; Nikolaou, A.; Batra, G.; Mantzourani, I.; Alexopoulos, A.; Plessas, S. Microbiological and Chemical Properties of Chokeberry Juice Fermented by Novel Lactic Acid Bacteria with Potential Probiotic Properties during Fermentation at $4{ }^{\circ} \mathrm{C}$ for 4 Weeks. Foods 2021, 10, https://doi.org/10.3390/foods10040768.

3. Lavefve, L.; Howard, L.R.; Carbonero, F. Berry polyphenols metabolism and impact on human gut microbiota and health. Food Funct. 2020, 11, 45-65, https://doi.org/10.1039/C9FO01634A.

4. Zhang, Y.; Long, Y.; Yu, S.; Li, D.; Yang, M.; Guan, Y.; Zhang, D.; Wan, J.; Liu, S.; Shi, A.; Li, N.; Peng, W. Natural volatile oils derived from herbal medicines: A promising therapy way for treating depressive disorder. Pharmacol. Res. 2021, 164, 105376, https://doi.org/10.1016/j.phrs.2020.105376.

5. Gajic, D.; Saksida, T.; Koprivica, I.; Vujicic, M.; Despotovic, S.; Savikin, K.; Jankovic, T.; Stojanovic, I. Chokeberry (Aronia melanocarpa) fruit extract modulates immune response in vivo and in vitro. J. Funct. Foods 2020, 66, 103836, https://doi.org/10.1016/j.jff.2020.103836.

6. Wang, L.; Sang, W.; Xu, R.; Cao, J. Alteration of flesh color and enhancement of bioactive substances via the stimulation of anthocyanin biosynthesis in 'Friar' plum fruit by low temperature and the removal. Food Chem. 2020, 310, 125862, https://doi.org/10.1016/j.foodchem.2019.125862.

7. Li, T.; Jiang, T.; Liu, N.; Wu, C.; Xu, H.; Lei, H. Biotransformation of phenolic profiles and improvement of antioxidant capacities in jujube juice by select lactic acid bacteria. Food Chem. 2021, 339, 127859, https://doi.org/10.1016/j.foodchem.2020.127859.

8. Prat-García, S.; Oliveira, J.; del Alamo-Sanza, M.; de Freitas, V.; Nevares, I.; Mateus, N. Characterization of Anthocyanins and Anthocyanin-Derivatives in Red Wines during Ageing in Custom Oxygenation Oak Wood Barrels. Molecules 2021, 26, https://doi.org/10.3390/molecules26010064.

9. Zhao, Y.; Zhu, H.; Xu, J.; Zhuang, W.; Zheng, B.; Lo, Y.M.; Huang, Z.; Tian, Y. Microwave vacuum drying of lotus (Nelumbo nucifera Gaertn.) seeds: Effects of ultrasonic pretreatment on color, antioxidant activity, and rehydration capacity. LWT 2021, 149, 111603, https://doi.org/10.1016/j.lwt.2021.111603.

10. Ghalandari, B.; Monajjemi, M.; Mollaamin, F. Theoretical Investigation of Carbon Nanotube Binding to DNA in View of Drug Delivery. Journal of Computational and Theoretical Nanoscience 2011, 8, 1212-1219, https://doi.org/10.1166/jctn.2011.1801.

11. Monajjemi, M.; Afsharnezhad, S.; Jaafari, M.R.; Mirdamadi, S.; Mollaamin, F.; Monajemi, H. Investigation of energy and NMR isotropic shift on the internal rotation Barrier of $\Theta 4$ dihedral angle of the DLPC: A GIAO study. Chemistry 2008, 17, 1.

12. Kodagoda, G.; Hong, H.T.; O’Hare, T.J.; Sultanbawa, Y.; Topp, B.; Netzel, M.E. Effect of Storage on the Nutritional Quality of Queen Garnet Plum. Foods 2021, 10, https://doi.org/10.3390/foods10020352.

13. Long, Y.; Schiefelbein, J. Novel TTG1 Mutants Modify Root-Hair Pattern Formation in Arabidopsis. Frontiers in Plant Science 2020, 11, 383, https://doi.org/10.3389/fpls.2020.00383.

14. Bakhshi, K.; Mollaamin, F.; Monajjemi, M. Exchange and Correlation Effect of Hydrogen Chemisorption on Nano V(100) Surface: A DFT Study by Generalized Gradient Approximation (GGA). Journal of Computational and Theoretical Nanoscience 2011, 8, 763-768, https://doi.org/10.1166/jctn.2011.1750. 
15. Bustillo Trueba, P.; Jaskula-Goiris, B.; Ditrych, M.; Filipowska, W.; De Brabanter, J.; De Rouck, G.; Aerts, G.; De Cooman, L.; De Clippeleer, J. Monitoring the evolution of free and cysteinylated aldehydes from malt to fresh and forced aged beer. Food Res. Int. 2021, 140, 110049, https://doi.org/10.1016/j.foodres.2020.110049.

16. Hong, H.T.; Phan, A.D.T.; O’Hare, T.J. Temperature and Maturity Stages Affect Anthocyanin Development and Phenolic and Sugar Content of Purple-Pericarp Supersweet Sweetcorn during Storage. J. Agric. Food Chem. 2021, 69, 922-931, https://doi.org/10.1021/acs.jafc.0c06153.

17. Monajjemi, M.; Mollaamin, F.; Gholami, M.R.; Yoosbashizadeh, H.; Sadrnezhad, S.K.; Passdar, H. Quantum Chemical Parameters of Some Organic Corrosion Inhibitors, Pyridine, 2-Picoline 4-Picoline and 2, 4Lutidine, Adsorption at Aluminum Surface in Hydrocholoric and Nitric Acids and Comparison Between Two Acidic Media. Main Group Met. Chem. 2003, 26, 349-362, https://doi.org/10.1515/MGMC.2003.26.6.349.

18. V. González de Peredo, A.; Vázquez-Espinosa, M.; Espada-Bellido, E.; Ferreiro-González, M.; AmoresArrocha, A.; Palma, M.; F. Barbero, G.; Jiménez-Cantizano, A. Alternative Ultrasound-Assisted Method for the Extraction of the Bioactive Compounds Present in Myrtle (Myrtus communis L.). Molecules 2019, 24, https://doi.org/10.3390/molecules24050882.

19. Aliaño-González, M.J.; Ferreiro-González, M.; Espada-Bellido, E.; Carrera, C.; Palma, M.; Ayuso, J.; Barbero, G.F.; Álvarez, J.Á. Extraction of Anthocyanins and Total Phenolic Compounds from Açai (Euterpe oleracea Mart.) Using an Experimental Design Methodology. Part 3: Microwave-Assisted Extraction. Agronomy 2020, 10, https://doi.org/10.3390/agronomy10020179.

20. Monajjemi, M.; Mahdavian, L.; Mollaamin, F.; Khaleghian, M. Interaction of Na, Mg, Al, Si with carbon nanotube (CNT): NMR and IR study. Russian Journal of Inorganic Chemistry 2009, 54, 1465-1473, https://doi.org/10.1134/S0036023609090216.

21. Sarasia, E.M.; Afsharnezhad, S.; Honarparvar, B.; Mollaamin, F.; Monajjemi, M. Theoretical study of solvent effect on NMR shielding tensors of luciferin derivatives. PCL 2011, 49, 561-571, https://doi.org/10.1080/00319101003698992.

22. Krüger, E.; Will, F.; Kumar, K.; Celejewska, K.; Chartier, P.; Masny, A.; Mott, D.; Petit, A.; Savini, G.; Sønsteby, A. Influence of Post-Flowering Climate Conditions on Anthocyanin Profile of Strawberry Cultivars Grown from North to South Europe. Applied Sciences 2021, 11, https://doi.org/10.3390/app11031326.

23. He, Q.; Ren, Y.; Zhao, W.; Li, R.; Zhang, L. Low Temperature Promotes Anthocyanin Biosynthesis and Related Gene Expression in the Seedlings of Purple Head Chinese Cabbage (Brassica rapa L.). Genes 2020, 11, https://doi.org/10.3390/genes11010081.

24. Hu, X.; Liu, H.; Yu, Y.; Li, G.; Qi, X.; Li, Y.; Li, T.; Guo, X.; Liu, R.H. Accumulation of phenolics, antioxidant and antiproliferative activity of sweet corn (Zea mays L.) during kernel maturation. Int. J. Food Sci. Tech. 2021, 56, 2462-2470, https://doi.org/10.1111/ijfs.14879.

25. Cmejla, R.; Zdarska, I.; Suran, P.; Paprstein, F.; Cmejlova, J. A new allelic discrimination real-time PCR assay for PavMYB10.1 genotyping to predict sweet cherry fruit colour: a comparison with the Pav-Rf-SSR assay. The Journal of Horticultural Science and Biotechnology 2021, 96, 260-269, https://doi.org/10.1080/14620316.2020.1837021.

26. Covello, A.L.; Horwitz, L.I.; Singhal, S.; Blaum, C.S.; Li, Y.; Dodson, J.A. Cardiovascular disease and cumulative incidence of cognitive impairment in the Health and Retirement Study. BMC Geriatr. 2021, 21, 274, https://doi.org/10.1186/s12877-021-02191-0.

27. Shao, D.; Li, Y.; Zhu, Q.; Zhang, X.; Liu, F.; Xue, F.; Sun, J. GhGSTF12, a glutathione S-transferase gene, is essential for anthocyanin accumulation in cotton (Gossypium hirsutum L.). Plant Sci. 2021, 305, 110827 , https://doi.org/10.1016/j.plantsci.2021.110827.

28. Badon, S.E.; Gabriel, K.P.; Karvonen-Gutierrez, C.; Sternfeld, B.; Gold, E.B.; Waetjen, L.E.; Lee, C.; Avalos, L.A.; El Khoudary, S.R.; Hedderson, M.M. Dual trajectories of physical activity and blood lipids in midlife women: The Study of Women's Health Across the Nation. Maturitas 2021, 146, 49-56, https://doi.org/10.1016/j.maturitas.2021.02.002.

29. Zhou, D.; Li, R.; Zhang, H.; Chen, S.; Tu, K. Hot air and UV-C treatments promote anthocyanin accumulation in peach fruit through their regulations of sugars and organic acids. Food Chem. 2020, 309, 125726, https://doi.org/10.1016/j.foodchem.2019.125726. 
30. Zhang, B.; Yang, H.-J.; Yang, Y.-Z.; Zhu, Z.-Z.; Li, Y.-N.; Qu, D.; Zhao, Z.-Y. mdm-miR828 Participates in the Feedback Loop to Regulate Anthocyanin Accumulation in Apple Peel. Frontiers in Plant Science 2020, 11, 1905, https://doi.org/10.3389/fpls.2020.608109.

31. Bardak, A.; Çelik, S.; Erdoğan, O.; Ekinci, R.; Dumlupinar, Z. Association Mapping of Verticillium Wilt Disease in a Worldwide Collection of Cotton (Gossypium hirsutum L.). Plants 2021, 10, https://doi.org/10.3390/plants10020306.

32. Li, Z.; Wang, X.; Cao, X.; Chen, B.; Ma, C.; Lv, J.; Sun, Z.; Qiao, K.; Zhu, L.; Zhang, C.; Fan, S.; Ma, Q. GhTULP34, a member of tubby-like proteins, interacts with GhSKP1A to negatively regulate plant osmotic stress. Genomics 2021, 113, 462-474, https://doi.org/10.1016/j.ygeno.2020.09.024.

33. Vugic, L.; Colson, N.; Nikbakht, E.; Gaiz, A.; Holland, O.J.; Kundur, A.R.; Singh, I. Anthocyanin supplementation inhibits secretion of pro-inflammatory cytokines in overweight and obese individuals. $J$. Funct. Foods 2020, 64, 103596, https://doi.org/10.1016/j.jff.2019.103596.

34. Conrad, I.; Craft, A.; Thurman, C.L.; Baeza, J.A. The complete mitochondrial genome of the red-jointed brackish-water fiddler crab Minuca minax (LeConte 1855) (Brachyura: Ocypodidae): New family gene order, and purifying selection and phylogenetic informativeness of protein coding genes. Genomics 2021, 113, 565572, https://doi.org/10.1016/j.ygeno.2020.09.050.

35. Liu, Q.-N.; Tang, Y.-Y.; Yang, T.-T.; Li, Y.-T.; Yu, X.-M. Phylogenetic relationships of Grapsoidea and insights into the higher phylogeny of Brachyuran. Genomics 2021, 113, 429-439, https://doi.org/10.1016/j.ygeno.2020.08.033.

36. Oppi, S.; Lüscher, T.F.; Stein, S. Mouse Models for Atherosclerosis Research-Which Is My Line? Frontiers in Cardiovascular Medicine 2019, 6, 46, https://doi.org/10.3389/fcvm.2019.00046.

37. Singh, G.; Singh, V.; Singh, V. Genome-wide interologous interactome map (TeaGPIN) of Camellia sinensis. Genomics 2021, 113, 553-564, https://doi.org/10.1016/j.ygeno.2020.09.048.

38. Frisch, M.J.; Trucks, G.W.; Schlegel, H.B.; Scuseria, G.E.; Robb, M.A.; Cheeseman, J.R.; Scalmani, G.; Barone, V.; Mennucci, B.; Petersson, G.A. Gaussian, Inc., Wallingford CT. Gaussian 092009.

39. Mollaamin, F.; Monajjemi, M. Harmonic Linear Combination and Normal Mode Analysis of Semiconductor Nanotubes Vibrations. Journal of Computational and Theoretical Nanoscience 2015, 12, 1030-1039, https://doi.org/10.1166/jctn.2015.3846.

40. Nicolia, A.; Andersson, M.; Hofvander, P.; Festa, G.; Cardi, T. Tomato protoplasts as cell target for ribonucleoprotein (RNP)-mediated multiplexed genome editing. Plant Cell, Tissue and Organ Culture (PCTOC) 2021, 144, 463-467, https://doi.org/10.1007/s11240-020-01954-8.

41. Zhao, Y.; Chen, W.; Cui, Y.; Sang, X.; Lu, J.; Jing, H.; Wang, W.; Zhao, P.; Wang, H. Detection of candidate genes and development of KASP markers for Verticillium wilt resistance by combining genome-wide association study, QTL-seq and transcriptome sequencing in cotton. Theor. Appl. Genet. 2021, 134, 10631081, https://doi.org/10.1007/s00122-020-03752-4.

42. Wang, Y.; Liu, W.; Wang, X.; Yang, R.; Wu, Z.; Wang, H.; Wang, L.; Hu, Z.; Guo, S.; Zhang, H.; Lin, J.; $\mathrm{Fu}, \mathrm{C}$. MiR156 regulates anthocyanin biosynthesis through SPL targets and other microRNAs in poplar. Horticulture Research 2020, 7, 118, https://doi.org/10.1038/s41438-020-00341-w.

43. Khaleghian, M.; Zahmatkesh, M.; Mollaamin, F.; Monajjemi, M. Investigation of Solvent Effects on Armchair Single-Walled Carbon Nanotubes: A QM/MD Study. Fullerenes, Nanotubes and Carbon Nanostructures 2011, 19, 251-261, https://doi.org/10.1080/15363831003721757.

44. Monajjemi, M.; Baie, M.T.; Mollaamin, F. Interaction between threonine and cadmium cation in [Cd(Thr)n]2+ ( $=1-3)$ complexes: density functional calculations. Russ. Chem. Bull. 2010, 59, 886-889, https://doi.org/10.1007/s11172-010-0181-5.

45. Cohen, G.; Eisenberg, H. Deoxyribonueleate solutions: Sedimentation in a density gradient, partial specific volumes, density and refractive index increments, and preferential interactions. Biopolymers 1968, 6, 10771100, https://doi.org/10.1002/bip.1968.360060805.

46. Bæksted Holme, I.; Dionisio, G.; Brinch-Pedersen, H. A Roadmap to Modulated Anthocyanin Compositions in Carrots. 2021, 10, 472, https://doi.org/10.3390/plants10030472.

47. Kirkwood, J.G. Theory of solutions of molecules containing widely separated charges with special application to zwitterions. The Journal of Chemical Physics 1934, 2, 351-361, https://doi.org/10.1063/1.1749489. 
48. Kirkwood, J.G. The dielectric polarization of polar liquids. The Journal of Chemical Physics 1939, 7, 911919https://doi.org/10.1063/1.1750343.

49. Onsager, L. Electric Moments of Molecules in Liquids. J. Am. Chem. Soc. 1936, 58, 1486-1493, https://doi.org/10.1021/ja01299a050.

50. Wong, M.W.; Frisch, M.J.; Wiberg, K.B. Solvent effects. 1. The mediation of electrostatic effects by solvents. J. Am. Chem. Soc. 1991, 113, 4776-4782, https://doi.org/10.1021/ja00013a010.

51. Wong, M.W.; Wiberg, K.B.; Frisch, M.J. Solvent effects. 2. Medium effect on the structure, energy, charge density, and vibrational frequencies of sulfamic acid. J. Am. Chem. Soc. 1992, 114, 523-529, https://doi.org/10.1021/ja00028a019.

52. Lee, V.S.; Nimmanpipug, P.; Mollaamin, F.; Kungwan, N.; Thanasanvorakun, S.; Monajjemi, M. Investigation of single wall carbon nanotubes electrical properties and normal mode analysis: Dielectric effects. Russian Journal of Physical Chemistry A 2009, 83, 2288-2296, https://doi.org/10.1134/S0036024409130184.

53. Monajjemi, M.; Farahani, N.; Mollaamin, F. Thermodynamic study of solvent effects on nanostructures: phosphatidylserine and phosphatidylinositol membranes. PCL 2012, 50, 161-172, https://doi.org/10.1080/00319104.2010.527842.

54. Tahan, A.; Mollaamin, F.; Monajjemi, M. Thermochemistry and NBO analysis of peptide bond: Investigation of basis sets and binding energy. Russian Journal of Physical Chemistry A 2009, 83, 587-597, https://doi.org/10.1134/S003602440904013X.

55. Mollaamin, F.; Monajjemi, M.; Salemi, S.; Baei, M.T. A Dielectric Effect on Normal Mode Analysis and Symmetry of BNNT Nanotube. Fullerenes, Nanotubes and Carbon Nanostructures 2011, 19, 182-196, https://doi.org/10.1080/15363831003782932.

56. Sun, C.; Deng, L.; Du, M.; Zhao, J.; Chen, Q.; Huang, T.; Jiang, H.; Li, C.-B.; Li, C. A transcriptional network promotes anthocyanin biosynthesis in tomato flesh. Molecular plant 2020, 13, 42-58, https://doi.org/10.1016/j.molp.2019.10.010.

57. Rodriguez-Amaya, D.B. Update on natural food pigments - A mini-review on carotenoids, anthocyanins, and betalains. Food Res. Int. 2019, 124, 200-205, https://doi.org/10.1016/j.foodres.2018.05.028.

58. Ali, M.M.; Anwar, R.; Yousef, A.F.; Li, B.; Luvisi, A.; De Bellis, L.; Aprile, A.; Chen, F. Influence of Bagging on the Development and Quality of Fruits. Plants 2021, 10, https://doi.org/10.3390/plants10020358.

59. HyperChem, version 8.0; Hypercube Inc: Gainesville, FL, USA, 2007.

60. Monajjemi, M.; Noei, M.; Mollaamin, F. Design of fMet-tRNA and Calculation of its Bonding Properties by Quantum Mechanics. Nucleosides Nucleotides Nucl. Acids 2010, 29, 676-683, https://doi.org/10.1080/15257771003781642. 